\title{
Relationships between Hydraulic Parameters of the Nubian Aquifer and Wells in El Shab Area, South Western Desert, Egypt (A Case Study)
}

\author{
Maged El Osta \\ Geology Department, Faculty of Science, Damanhour University, Damanhour, Egypt \\ Email: drmagedelosta.edu.alex@hotmail.com
}

Received August 15, 2012; revised September 14, 2012; accepted October 12, 2012

\begin{abstract}
For proper water management in the new reclaimed areas, hydraulic parameters of both aquifer and wells related to transmissivity, specific capacity, well loss, formation loss, and water entrance velocity, as well as the relationship between these parameters are the main target after construction of production wells. In El Shab area, the Nubian Sandstone aquifer has a large range of transmissivity (from 483.12 to $1489.24 \mathrm{~m}^{2} /$ day) and, also, specific capacity (from 203 to $486.32 \mathrm{~m}^{2} /$ day). Relationship of specific capacity and transmissivity is constructed and the established empirical equations can be used to predict the transmissivity of the Nubian aquifer in all new proposed sites for well drilling at which the specific capacity measured without performing pumping tests. On the other hand, the drilled wells in El Shab area exhibit relatively high well losses $(25 \%)$. The causes for high well losses (entrance velocity (Vn) through water well screen and the distance from the point of water entrance in the well to the point of intake in the pump) are discussed and the relationships are constructed, which seem a positive linear correlation. Relationships between well losses constant for 30 wells with transmissivity and specific capacity, are constructed. These relationships are useful for estimating hydraulic characteristics that are needed for the designs of wells and well fields and for preliminary water-resources management.
\end{abstract}

Keywords: Nubian Sandstone Aquifer; Transmissivity; Specific Capacity; Well Loss; Entrance Velocity; Well Efficiency

\section{Introduction}

El Shab area, lies in south of the Western Desert and is considered as natural extension of Darb El Arbaein project (Figure 1). In Darb El-Arbaein, the groundwater is the only water resource. The aquifer system starts from Paleozoic-Mesozoic to Upper Cretaceous sandstone rocks overlaying the basement rocks with confined condition. They irrigate 12,000 feddans ( 1 feddan $\approx 1.038$ acres) and help 16 villages for farmers along about $400 \mathrm{~km}$ from Paris town towards the Egypt-Sudan border. The pumping wells are located in three parts: the northern, the central, and the southern part of Darb El-Arbaein. The northern part extends $90 \mathrm{~km}$ to the south from Paris town and has an area of $90 \mathrm{~km}^{2}$. The central part extends $80 \mathrm{~km}$ to the south of the northern part and has $120 \mathrm{~km}^{2}$ in area. The southern part (El Shab area) extends $200 \mathrm{~km}$ to the south of the central part and has $170 \mathrm{~km}^{2}$ in area. The Darb El-Arbaein is located in an arid region where the absolute maximum air temperature is $48.6^{\circ} \mathrm{C}$ in May and minimum air temperature is $2^{\circ} \mathrm{C}$ in February. The annual rainfall is $<1.1 \mathrm{~mm}$, and the total monthly rainfall is $0.3 \mathrm{~mm}$. The annual evaporation is about $172 \mathrm{~mm}$, and the maximum evaporation rate in June is about $21.32 \mathrm{~mm}$. The evaluating of water resources and their use is main target for proper management in this new reclaimed area. The purpose of ground-water development in this arid region, is to bring about an additional supply of water, whether it be used for agricultural, domestic, industrial, or other purposes. An understanding of the various factors causing excessive well losses is important because savings in well design and construction and operation can be made by increasing the efficiency of a well and thus preventing much needless waste of materials pumping energy.

In this paper, an attempt is made to evaluate the factors causing excessive well losses in El Shab area and to relate the wells and aquifer hydraulic characteristics to find out the relationship between these hydraulic parameters. These relationships are useful for estimating hydraulic characteristics that are needed for the designs of wells and for preliminary water resources management. 


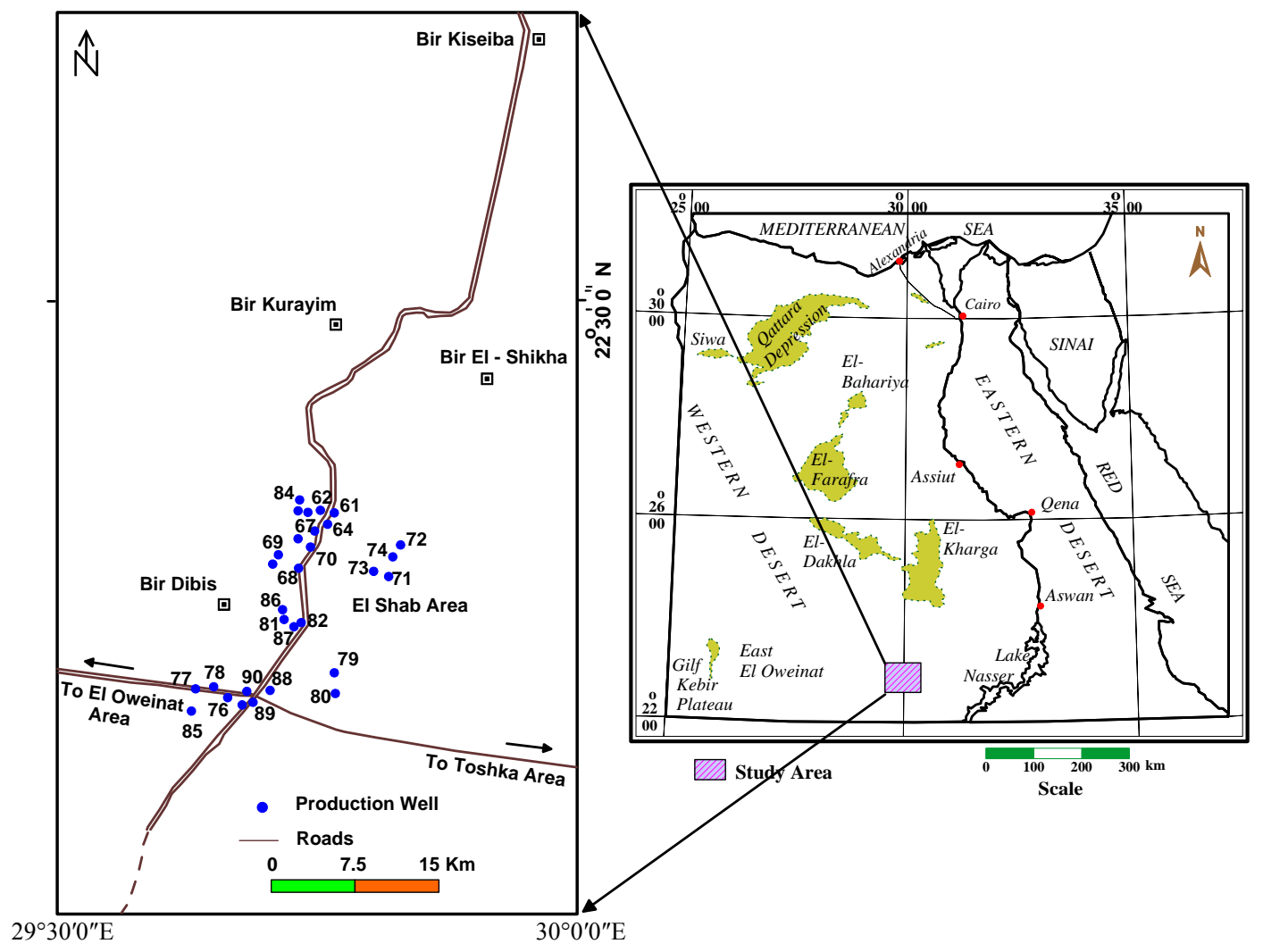

Figure 1. Location map of El Shab area, South Western desert, Egypt.

\section{Geological and Hydrogeological Conditions}

Geologically, the exposed rocks in Darb El-Arbaein range from Pre-Cambrian to Quaternary sediments (CO- NOCO [1]). The lithostratigraphic successions are divided into seven units, from base to top (CONOCO [1]; Fathy et al. [2]; Korany et al. [3]; Ghazal [4]; El Gammal [5]): 1) Pre-Cambrian basement; 2) Paleozoic-Mesozoic sandstone; 3) Lower Cretaceous; 4) Upper Cretaceous; 5) Paleocene; 6) Eocene; and 7) Quaternary. The Nubian sandstone is classified into Shab, Qusier, and Taref members (Issawi [6]). The Kiseiba Formation is equivalent to both Shab and Qusier members and Taref is equivalent to Taref member. The Dakhla shale represents the capping aquifer only in the central and northern Darb El-Arbaein. The sedimentary cover increases far in the northern part (more than $100 \mathrm{~m}$ ), while it decreases to the southern part of the northern Darb El-Arbaein. The lithostratigraphic sequence in the southern part of Darb El-Arbaein (El Shab area) is mainly composed of Kiseiba and Taref Formations with a little thickness variation (Figure 2).

Hydrogeologically, 30 production wells are drilled and constructed (year 2001) in the Nubian Sandstone aquifer by the Research and Ground Water Co. (REWA) in a project for developing the area of the New Valley Governorate (Figure 1). The regional hydrogeological section constructed along Darb E1 Arbaein area (Figure 3) shows that the Nubian aquifer in the concerned area is the unique source of fresh water and built of Kiseiba and Taref Formations of the Upper Cretaceous. The upper most layer of Kiseiba Formation acts as a confining layer. The aquifer thickness increases in the southern part, attributed to high concentration of faults to the north. The aquifer is composed of coarse-grained sandstone at the base that changes gradually to fine and medium upward. It directly overlies the basement rocks. The drilled depth of wells is running almost between 120 and $210 \mathrm{~m}$ (reached the basement complex). The details of drilling and well design are shown in Table 1, which includes the whole wells. After deciding the production well assembly, the pilot hole is reamed to proper diameter and the well assembly is set in position by placing the specified slotted section against the water zones. Gravel of proper size is shrouded between the well assembly and the walls of the borehole, and the well is washed thoroughly. The wells are developed by backwashing and airlifting. The lifting pump is sited for a depth between 25 and $42 \mathrm{~m}$ only, which may not be suitable for the expected amount of water withdrawn from the wells $\left(200 \mathrm{~m}^{3} / \mathrm{h} /\right.$ well and for 12 hours daily) as well as the expected head decline in wells. The estimated transmissivity of the Nubian aquifer from pumping tests analysis ranges between $483.12 \mathrm{~m}^{2}$ /day 


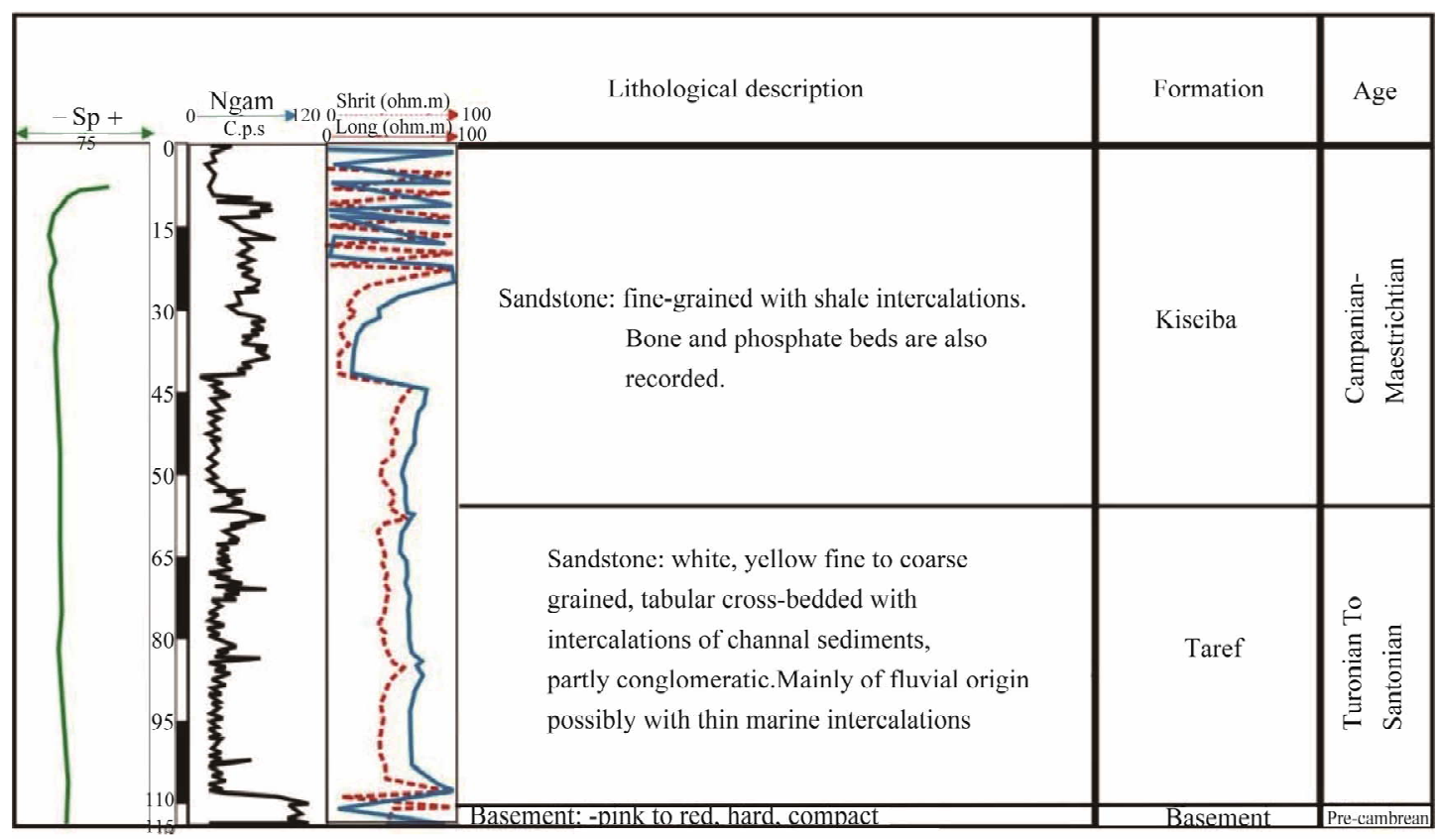

Figure 2. Lithostratigraphic sequence in El Shab area, South Western desert, Egypt.

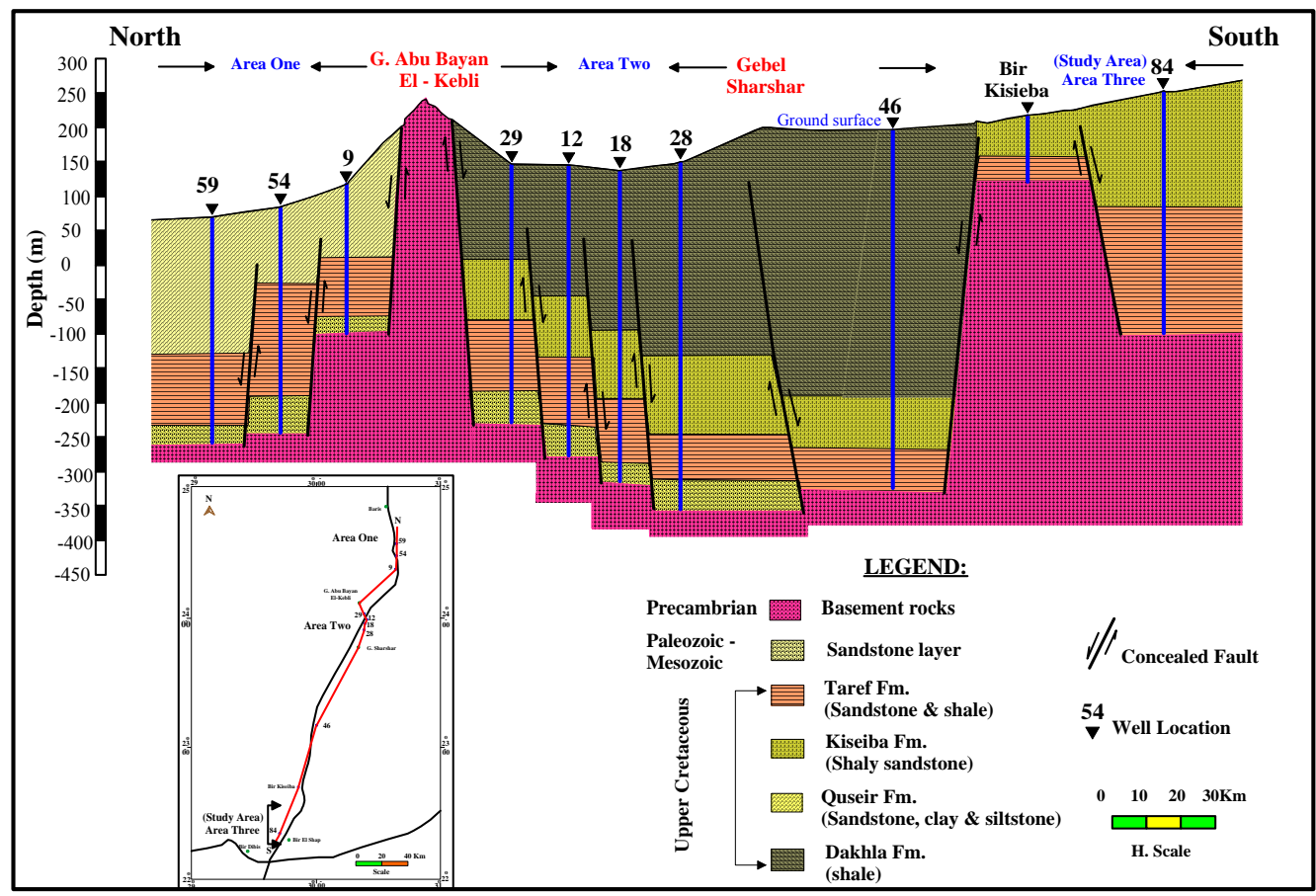

Figure 3. A very generalized hydrogeological cross section along the three areas of Darb El Arbaein.

(well No. 62) and $1489.24 \mathrm{~m}^{2} /$ day (well No. 89). This wide variation may be attributed to the rapid lateral facies changes as well as the variation in the thickness of the productive water bearing units.

\section{Materials and Methods}

The materials used in this paper were collected through carrying out two field trips in E1 Shab area in 2010 year, in which the following activities were performed: 1) Inventory of the existing water wells; 2) Carrying out, depth to water measurements from the ground surface in 30 water wells; 3) Registration of wells discharge. The other basic hydrologic materials were got from the Ministry of Water Resources and Irrigation, Groundwater sector, El Wadi El Gidid area during these field trips. 
Table 1. Data for wells in El Shab area (Data source: ministry of water resources and irrigation, groundwater sector, El wadi El gidid area[7]).

\begin{tabular}{|c|c|c|c|c|c|c|c|c|c|}
\hline \multirow{2}{*}{$\begin{array}{l}\text { Well } \\
\text { No. }\end{array}$} & \multirow{2}{*}{$\begin{array}{l}\text { Well Total } \\
\text { Depth (m) }\end{array}$} & \multicolumn{2}{|c|}{ Screen Length (m) } & \multirow{2}{*}{$\begin{array}{c}\text { Depth to } \\
\text { Water } \\
(\mathrm{m})\end{array}$} & \multirow{2}{*}{$\begin{array}{l}\text { Pump } \\
\text { Position } \\
(\mathrm{m})\end{array}$} & \multirow{2}{*}{$\begin{array}{c}\text { Discharge Q } \\
\left(\mathrm{m}^{3} / \mathrm{h}\right)\end{array}$} & \multirow{2}{*}{$\begin{array}{l}\text { Drawdown } \\
\mathrm{S}(\mathrm{m})\end{array}$} & \multirow{2}{*}{$\begin{array}{c}\text { Transmissivity } \\
\mathrm{T} \text { (pumping) } \\
\left(\mathrm{m}^{2} / \text { day }\right)\end{array}$} & \multirow{2}{*}{$\begin{array}{c}\text { Specific } \\
\text { Capacity } \\
\text { Sc }\left(\mathrm{m}^{2} / \text { day }\right)\end{array}$} \\
\hline & & From & To & & & & & & \\
\hline 61 & 194 & 79.8 & 194 & 1.1 & 40 & 225 & 21.02 & 610.00 & 256.89 \\
\hline 62 & 125 & 79 & 125 & 2.23 & 35 & 120 & 13.4 & 483.12 & 214.92 \\
\hline 63 & 180.5 & 77.58 & 180.5 & 1.4 & 25 & 150 & 12.18 & 563.52 & 295.55 \\
\hline 64 & 186 & 77.39 & 186 & 0.35 & 25 & 195 & 12.2 & 643.92 & 383.6 \\
\hline 65 & 197 & 77.2 & 197 & 1.4 & 25 & 180 & 13.1 & 886.85 & 329.77 \\
\hline 66 & 174.7 & 88.84 & 174.7 & 0.3 & 30 & 180 & 15.15 & 845.7 & 285.14 \\
\hline 67 & 174.5 & 88.62 & 174.5 & 3.6 & 25 & 180 & 12.88 & 859.70 & 335.4 \\
\hline 68 & 157 & 84.8 & 157 & 0.22 & 30 & 200 & 19.97 & 698.82 & 240.36 \\
\hline 69 & 155 & 87.7 & 155 & 0.4 & 25 & 200 & 12.89 & 722.30 & 372.38 \\
\hline 70 & 159.5 & 82.98 & 159.5 & 0.52 & 30 & 190 & 16.39 & 665.20 & 278.21 \\
\hline 71 & 163 & 86.06 & 163 & 0.1 & 25 & 180 & 10.96 & 1047.14 & 394.16 \\
\hline 72 & 160.5 & 80.49 & 160.5 & 6.15 & 30 & 200 & 21.11 & 650.76 & 227.38 \\
\hline 73 & 148 & 85.0 & 148 & 6.7 & 40 & 180 & 21.28 & 933.36 & 203.00 \\
\hline 74 & 174.5 & 85.33 & 174.5 & 7.0 & 30 & 200 & 13.88 & 1201.04 & 345.82 \\
\hline 75 & 207.5 & 87.61 & 207.5 & 5.7 & 30 & 180 & 10.15 & 1332.96 & 425.6 \\
\hline 76 & 190 & 91.36 & 190 & 11.20 & 35 & 180 & 13.89 & 1163.20 & 311.01 \\
\hline 77 & 205 & 90.71 & 205 & 10.95 & 42 & 185 & 17.51 & 1100.89 & 253.56 \\
\hline 78 & 196.4 & 93.49 & 196.4 & 9.05 & 35 & 180 & 16.40 & 935.570 & 263.41 \\
\hline 79 & 204.6 & 90.36 & 204.6 & 11.30 & 32 & 180 & 13.48 & 1247.14 & 320.47 \\
\hline 80 & 176.2 & 90.41 & 176.2 & 6.08 & 32 & 180 & 16.84 & 1188.90 & 256.5 \\
\hline 81 & 173 & 87.07 & 173 & 7.05 & 33 & 180 & 13.68 & 927.50 & 315.78 \\
\hline 82 & 203 & 91.32 & 203 & 8.7 & 27 & 180 & 12.02 & 1179.57 & 359.40 \\
\hline 83 & 118 & 72.12 & 118 & 3.55 & 25 & 180 & 12.75 & 571.70 & 338.82 \\
\hline 84 & 114 & 71.83 & 114 & 0.8 & 25 & 180 & 12.39 & 725.40 & 348.99 \\
\hline 85 & 200 & 91.31 & 200 & 12.34 & 33 & 180 & 11.41 & 1296.35 & 378.61 \\
\hline 86 & 197 & 88.19 & 197 & 7.72 & 25 & 190 & 11.00 & 1390.80 & 414.54 \\
\hline 87 & 199 & 90.12 & 199 & 8.64 & 30 & 190 & 9.86 & 1424.50 & 462.47 \\
\hline 88 & 191 & 88.22 & 191 & 8.55 & 36 & 200 & 11.75 & 1335.98 & 408.51 \\
\hline 89 & 193.5 & 90.5 & 193.5 & 7.65 & 30 & 200 & 9.87 & 1489.24 & 486.32 \\
\hline 90 & 196.5 & 91.42 & 196.5 & 10.18 & 33 & 180 & 12.98 & 1285.55 & 332.81 \\
\hline
\end{tabular}

These materials include collection of archival data such as well drilling reports, pump position, screen length, proposed operating systems for both groundwater supply and reclaimed area beside step drawdown test data of 30 drilled wells. In addition, the methods applied in this work consists of the following steps:

\subsection{Calculating of Specific Capacity (Sc)}

Specific capacity is a measure of the productivity of a well. It is determined from a test that involves pumping a well at a constant rate and measuring the resulting drawdown in water level. Specific capacity is the parameter most often provided by drillers to characterize the performance of a well, both because it is easy to be measured and because well owners easily understand how much water they can get from the well. In contrast, estimation of transmissivity $(\mathrm{T})$ requires more rigorous, longer-term testing, which is expensive. This explains why $(\mathrm{Sc})$ data are much more abundant than $(\mathrm{T})$ data. As, transmissivity is the preferred parameters for many hydrogeologic purposes, it is common practice to calculate it from specific capacity data through the relationship established between these parameters. In mathematical terms, specific capacity $(\mathrm{Sc})$ is defined as the pumping rate $(\mathrm{Q})$ divided by 
the observed decline in hydraulic head in the well $(\Delta \mathrm{hw})$ and has the same dimensions of transmissivity ( $\mathrm{m}^{2} /$ day) as follows:

$$
\mathrm{Sc}=\mathrm{Q} / \Delta \mathrm{hw}
$$

For steady-state conditions, specific capacity of a well is a function of well radius, degree of aquifer penetration and transmissivity. It may also be increased by increasing the radius of the well and by increasing the percent penetration of the total saturated thickness of the aquifer. For transient conditions, it is also a function of time, well loss and storativity.

Well loss leads to miscalculation of specific capacity from what would be expected if specific capacity only reflected the productivity of the aquifer, as the total head decline in a well $(\Delta \mathrm{hw})$ is the sum of the head loss in the aquifer $(\Delta \mathrm{ha})$ at the well and the well loss $(\Delta \mathrm{hL})$, which represents the part of the drawdown in a well that is due to turbulent flow near the well, through the well screen and in the well casing.

$$
\Delta \mathrm{hw}=\Delta \mathrm{ha}+\Delta \mathrm{hL}
$$

which is also:

$$
\Delta \mathrm{hw}=\mathrm{BQ}+\mathrm{CQ}^{2}
$$

where $\mathrm{B}$ is the well function and $\mathrm{C}$ is the well-loss constant (Jacob [8]; Eagon and Johe [9]). If there is no well loss $(\mathrm{C}$ equals 0$)$ the specific capacity only reflected the productivity of the aquifer. If $\mathrm{C}$ is greater than 0 , well loss $(\mathrm{GhL})$ is nonzero, and the observed decline of hydraulic head in the well (Ghw) becomes larger leading to miscalculation of specific capacity of the well. Calculated specific capacity (Sc) for the 30 drilled well in El Shab area is shown in Table 1. The specific capacity, thus calculated, ranges between $203 \mathrm{~m}^{2} /$ day in well No. 73 (low productivity) and $486.32 \mathrm{~m}^{2} /$ day in well No. 89 (high productivity). This relatively wide variation may be due to the variation in the well loss of the productive water, which in turn is controlled by the placing of specified slotted section, total screen open area, gravel size between the well assembly and the walls of the borehole, and the position of lifting pump.

\subsection{Analysis of Step-Test Data}

The step drawdown pumping test is very important to determine the definite discharge and the efficiency of both aquifer and the wells. The drawdown in a well created due withdrawal of water, is usually made up of two types of head losses resulting from laminar flow in the formation (formation loss) and turbulent flow through the well screen and the well casing (well loss).

A step drawdown test data of 30 drilled wells in El Shab area were analyzed by the author using graphical method according to the following equation of Rorabaugh [10]
(Kruseman and de Ridder [11]):

$$
\mathrm{S}=\mathrm{BQ}+\mathrm{CQ}^{2}
$$

Where, $\mathrm{S}$ is the anticipated drawdown $(\mathrm{m}), \mathrm{Q}$ is the discharge rate $\left(\mathrm{m}^{3} / \mathrm{h}\right), \mathrm{B}$ is the formation loss coefficient $\left(\mathrm{h} / \mathrm{m}^{2}\right), \mathrm{C}$ is the well loss coefficient $\left(\mathrm{h}^{2} / \mathrm{m}^{5}\right)$.

By dividing the drawdown by the discharge rate of the well, the above equation changes as:

$$
\mathrm{S} / \mathrm{Q}=\mathrm{B}+\mathrm{CQ}
$$

The ratio S/Q is the specific drawdown (reciprocal of specific capacity) of the well.

On the other hand, the well efficiency percentage $(\gamma)$ at any pumping rate can be also calculated by applying the following equation:

$$
\gamma=\mathrm{BQ} /\left(\mathrm{BQ}+\mathrm{CQ}^{2}\right)
$$

By plotting the specific drawdown of the well against discharge rate for several steps, the well loss and formation loss coefficients ( $\mathrm{C}$ and $\mathrm{B}$ ) were determined from the slope and intercept of the straight line plots respectively. Two of these graphical representations are shown in Figure 4. Based on these graphical representations the values of the well loss $\left(\mathrm{CQ}^{2}\right)$, formation loss $(\mathrm{BQ})$, well loss percentage $\left(\mathrm{CQ}^{2} \%\right)$ and the well efficiency percentage $(\gamma)$ are calculated for each step and listed in Table 2.

The obtained results indicate that, the well loss coefficient ranges between $2.9 \times 10^{-5}\left(\mathrm{~h}^{2} / \mathrm{m}^{5}\right)$ in well No. 63 and $1.57 \times 10^{-4}\left(\mathrm{~h}^{2} / \mathrm{m}^{5}\right)$ in well No. 69 , while the formation loss coefficient varies from $0.0324\left(\mathrm{~h} / \mathrm{m}^{2}\right)$ in well No. 75 to $0.0942\left(\mathrm{~h} / \mathrm{m}^{2}\right)$ in well No. 72 . Moreover, the estimated total drawdown (formation loss + well loss) by the graphical method is very close to the actual drawdown observed in the well. However, the formation loss percentage (well efficiency) varies from $52 \%$ (well No. 69) to $98 \%$ (well No. 70 ), with an average of about $75 \%$. In contrast, the well loss percentage ranges between $2 \%$ (well No. 70) and $48 \%$ (well No. 69), with an average of about $25 \%$. These results indicate that the drilled wells in El Shab area exhibit relatively high well losses. For the proper design of a well, attempts should be made to keep the well loss to a possible minimum. It is therefore, necessary to find out the factors that cause the excess well losses in the well drilled in El Shab area. These factors may be attributed to: 1) the partly clogged interstices of the gravel back around the screens of the wells; 2) the low area of screen openings; and 3) the high distance from the point of water entrance in the well to the point of intake in the pump (pump position).

\subsection{Calculating of Entrance Velocity (Vn)}

Among the many important parameters that take into account in the design and operation of water wells for 
Table 2. Well and formation characteristics obtained from graphical method, in El Shab area.

\begin{tabular}{|c|c|c|c|c|c|c|c|c|c|c|c|}
\hline $\begin{array}{l}\text { Well } \\
\text { No. }\end{array}$ & Step & $\begin{array}{c}\text { Disch. } \\
\mathbf{Q} \\
\left(\mathbf{m}^{3} / \mathbf{h}\right)\end{array}$ & $\begin{array}{c}\text { D.D } \\
\text { S } \\
\text { (m) }\end{array}$ & $\begin{array}{c}\text { Specif. } \\
\text { D.D } \\
\text { S/Q } \\
\left(\mathbf{h} / \mathbf{m}^{2}\right)\end{array}$ & $\begin{array}{c}\text { Form. } \\
\text { Loss Coef } \\
\text { B }\left(\mathbf{h} / \mathbf{m}^{2}\right)\end{array}$ & $\begin{array}{l}\text { Well Loss } \\
\text { Coef. } \\
\text { C } \\
\left(\mathbf{h}^{2} / \mathbf{m}^{5}\right)\end{array}$ & $\begin{array}{c}\text { Form. } \\
\text { Loss } \\
\text { BQ } \\
(\mathbf{m})\end{array}$ & $\begin{array}{l}\text { Well } \\
\text { Loss } \\
\text { CQ } \\
\text { (m) } \\
\end{array}$ & $\begin{array}{c}\text { Total } \\
\text { D.D } \\
\text { BQ + CQ } \mathbf{Q}^{2} \\
(\mathbf{m})\end{array}$ & $\begin{array}{c}\text { Well } \\
\text { Efficiency } \\
\% \\
\text { (BQ \%) }\end{array}$ & $\begin{array}{c}\text { Well Loss } \\
\% \\
\left(C^{2} \%\right)\end{array}$ \\
\hline (1) & (2) & (3) & (4) & (5) & (6) & (7) & (8) & (9) & (10) & (11) & (12) \\
\hline \multirow{3}{*}{61} & 1 & 150 & 11.93 & 0.0795 & & & 10.08 & 1.89 & 11.97 & 84 & 16 \\
\hline & 2 & 200 & 16.85 & 0.0842 & 0.0672 & $8.42 \times 10^{-5}$ & 13.44 & 3.37 & 16.81 & 80 & 20 \\
\hline & 3 & 250 & 22.2 & 0.0888 & & & 16.8 & 5.26 & 20.06 & 84 & 16 \\
\hline \multirow{3}{*}{62} & 1 & 100 & 11.74 & 0.0939 & & & 7.84 & 1.57 & 9.41 & 83 & 16 \\
\hline & 2 & 150 & 17.46 & 0.1007 & 0.0778 & $1.57 \times 10^{-4}$ & 11.67 & 3.53 & 15.2 & 77 & 23 \\
\hline & 3 & 200 & 24.28 & 0.1096 & & & 15.56 & 6.28 & 21.64 & 72 & 28 \\
\hline \multirow{3}{*}{63} & 1 & 150 & 7.21 & 0.0364 & & & 4.84 & 0.65 & 5.49 & 88 & 12 \\
\hline & 2 & 200 & 9.41 & 0.0383 & 0.0323 & $2.9 \times 10^{-5}$ & 6.46 & 1.16 & 7.62 & 85 & 15 \\
\hline & 3 & 250 & 11.67 & 0.0396 & & & 8.07 & 1.81 & 9.68 & 83 & 17 \\
\hline \multirow{3}{*}{64} & 1 & 140 & 7.49 & 0.0535 & & & 5.73 & 1.66 & 7.39 & 77 & 23 \\
\hline & 2 & 180 & 10.08 & 0.056 & 0.0409 & $8.45 \times 10^{-5}$ & 7.36 & 2.74 & 10.1 & 73 & 27 \\
\hline & 3 & 220 & 12.93 & 0.0587 & & & 8.99 & 4.08 & 13.07 & 67 & 33 \\
\hline \multirow{3}{*}{65} & 1 & 150 & 10.22 & 0.0681 & & & 8.36 & 1.82 & 10.18 & 82 & 18 \\
\hline & 2 & 190 & 13.52 & 0.0711 & 0.0559 & $8.1 \times 10^{-5}$ & 10.62 & 2.92 & 13.54 & 78 & 22 \\
\hline & 3 & 230 & 17.2 & 0.0747 & & & 12.86 & 4.28 & 17.14 & 75 & 25 \\
\hline \multirow{3}{*}{66} & 1 & 150 & 11.35 & 0.0756 & & & 9.55 & 1.8 & 11.35 & 84 & 16 \\
\hline & 2 & 190 & 15.03 & 0.0791 & 0.0637 & $8 \times 10^{-5}$ & 12.1 & 2.87 & 14.57 & 83 & 17 \\
\hline & 3 & 230 & 18.88 & 0.082 & & & 14.65 & 4.23 & 18.68 & 78 & 22 \\
\hline \multirow{3}{*}{67} & 1 & 130 & 7.97 & 0.0613 & & & 6.81 & 1.16 & 7.57 & 90 & 10 \\
\hline & 2 & 170 & 10.97 & 0.0645 & 0.0524 & $7 \times 10^{-5}$ & 8.91 & 2.02 & 10.53 & 85 & 15 \\
\hline & 3 & 210 & 14.2 & 0.0676 & & & 11.06 & 3.07 & 14.13 & 78 & 12 \\
\hline \multirow{3}{*}{68} & 1 & 140 & 14.52 & 0.1037 & & & 13.15 & 1.42 & 14.57 & 90 & 10 \\
\hline & 2 & 170 & 18.12 & 0.1065 & 0.0939 & $7.26 \times 10^{-5}$ & 15.96 & 2.1 & 18.06 & 88 & 12 \\
\hline & 3 & 200 & 21.38 & 0.1094 & & & 18.78 & 2.9 & 21.68 & 87 & 13 \\
\hline \multirow{3}{*}{69} & 1 & 120 & 6.07 & 0.0505 & & & 4.17 & 2.26 & 6.43 & 65 & 35 \\
\hline & 2 & 160 & 10.15 & 0.0634 & 0.0349 & $1.57 \times 10^{-4}$ & 5.56 & 4.01 & 9.57 & 58 & 42 \\
\hline & 3 & 200 & 13.29 & 0.0664 & & & 6.58 & 6.28 & 12.66 & 52 & 48 \\
\hline \multirow{3}{*}{70} & 1 & 120 & 9.48 & 0.079 & & & 8.96 & 0.45 & 9.14 & 98 & 2 \\
\hline & 2 & 160 & 12.61 & 0.0788 & 0.0747 & $3.12 \times 10^{-5}$ & 11.95 & 0.8 & 12.75 & 94 & 6 \\
\hline & 3 & 200 & 16.3 & 0.0815 & & & 14.54 & 1.25 & 15.79 & 92 & 8 \\
\hline \multirow{3}{*}{71} & 1 & 140 & 7.66 & 0.0547 & & & 6.66 & 1.00 & 7.66 & 87 & 13 \\
\hline & 2 & 180 & 10.28 & 0.0571 & 0.0476 & $5.12 \times 10^{-5}$ & 8.57 & 1.66 & 10.23 & 84 & 16 \\
\hline & 3 & 220 & 12.91 & 0.0587 & & & 10.47 & 2.48 & 12.95 & 81 & 19 \\
\hline \multirow{3}{*}{72} & 1 & 140 & 14.86 & 0.1061 & & & 13.16 & 1.75 & 14.51 & 90 & 10 \\
\hline & 2 & 180 & 19.92 & 0.111 & 0.0942 & $8.92 \times 10^{-5}$ & 16.95 & 2.89 & 19.64 & 86 & 14 \\
\hline & 3 & 220 & 25 & 0.114 & & & 20.72 & 4.32 & 25.04 & 83 & 17 \\
\hline \multirow{3}{*}{73} & 1 & 140 & 15.05 & 0.107 & & & 12.54 & 2.48 & 15.02 & 83 & 17 \\
\hline & 2 & 170 & 18.84 & 0.112 & 0.0896 & $1.27 \times 10^{-4}$ & 15.23 & 3.67 & 18.90 & 80 & 20 \\
\hline & 3 & 200 & 22.98 & 0.114 & & & 17.52 & 5.08 & 22.60 & 77 & 23 \\
\hline \multirow{3}{*}{74} & 1 & 140 & 9.74 & 0.0695 & & & 8.20 & 1.54 & 9.74 & 84 & 16 \\
\hline & 2 & 180 & 13.12 & 0.073 & 0.0586 & $7.87 \times 10^{-5}$ & 10.55 & 2.55 & 13.10 & 80 & 20 \\
\hline & 3 & 220 & 16.68 & 0.076 & & & 12.85 & 3.81 & 16.66 & 77 & 23 \\
\hline
\end{tabular}


Continued

\begin{tabular}{|c|c|c|c|c|c|c|c|c|c|c|c|}
\hline & 1 & 120 & 5.42 & 0.045 & & & 3.87 & 1.55 & 5.42 & 71 & 29 \\
\hline \multirow[t]{3}{*}{75} & 2 & 160 & 8.04 & 0.05 & 0.0324 & $1.07 \times 10^{-4}$ & 5.16 & 2.73 & 7.89 & 65 & 35 \\
\hline & 3 & 200 & 10.87 & 0.054 & & & 6.48 & 4.28 & 10.76 & 60 & 40 \\
\hline & 1 & 140 & 9.57 & 0.068 & & & 7.56 & 1.56 & 9.12 & 83 & 17 \\
\hline \multirow[t]{3}{*}{76} & 2 & 180 & 13.13 & 0.073 & 0.0545 & $1.00 \times 10^{-4}$ & 9.72 & 3.24 & 12.56 & 77 & 13 \\
\hline & 3 & 220 & 16.92 & 0.077 & & & 11.68 & 4.64 & 16.32 & 72 & 18 \\
\hline & 1 & 140 & 12.05 & 0.086 & & & 10.18 & 1.91 & 12.09 & 89 & 11 \\
\hline \multirow[t]{3}{*}{77} & 2 & 180 & 16.33 & 0.091 & 0.0727 & $9.75 \times 10^{-5}$ & 13.06 & 3.16 & 16.22 & 80 & 20 \\
\hline & 3 & 220 & 20.71 & 0.094 & & & 15.95 & 4.72 & 20.67 & 77 & 23 \\
\hline & 1 & 120 & 9.46 & 0.079 & & & 7.95 & 1.51 & 9.46 & 84 & 16 \\
\hline \multirow[t]{3}{*}{78} & 2 & 160 & 13.54 & 0.084 & 0.0666 & $1.05 \times 10^{-4}$ & 10.65 & 2.67 & 13.32 & 80 & 20 \\
\hline & 3 & 200 & 17.78 & 0.087 & & & 13.32 & 4.20 & 17.52 & 76 & 24 \\
\hline & 1 & 120 & 8.09 & 0.067 & & & 6.96 & 1.04 & 8.00 & 87 & 13 \\
\hline \multirow[t]{3}{*}{79} & 2 & 160 & 11.21 & 0.07 & 0.0582 & $7.25 \times 10^{-5}$ & 9.31 & 1.86 & 11.17 & 83 & 17 \\
\hline & 3 & 200 & 14.5 & 0.072 & & & 11.64 & 2.9 & 14.54 & 80 & 20 \\
\hline & 1 & 120 & 9.6 & 0.08 & & & 7.63 & 1.97 & 9.60 & 79 & 21 \\
\hline \multirow[t]{3}{*}{80} & 2 & 160 & 13.82 & 0.086 & 0.0636 & $1.37 \times 10^{-4}$ & 10.17 & 3.51 & 13.68 & 74 & 26 \\
\hline & 3 & 200 & 18.23 & 0.091 & & & 12.72 & 5.48 & 18.2 & 70 & 30 \\
\hline & 1 & 140 & 9.4 & 0.067 & & & 7.77 & 1.67 & 9.44 & 82 & 18 \\
\hline \multirow[t]{3}{*}{81} & 2 & 180 & 12.83 & 0.071 & 0.0555 & $8.5 \times 10^{-5}$ & 9.59 & 2.75 & 12.34 & 78 & 22 \\
\hline & 3 & 220 & 16.5 & 0.075 & & & 12.21 & 4.11 & 16.32 & 75 & 25 \\
\hline & 1 & 140 & 8.42 & 0.06 & & & 6.54 & 1.81 & 8.35 & 78 & 22 \\
\hline \multirow[t]{3}{*}{82} & 2 & 180 & 11.4 & 0.063 & 0.0467 & $9.25 \times 10^{-5}$ & 8.40 & 2.96 & 11.36 & 74 & 26 \\
\hline & 3 & 220 & 14.74 & 0.067 & & & 10.27 & 4.48 & 14.75 & 70 & 30 \\
\hline & 1 & 120 & 7.00 & 0.058 & & & 6.27 & 0.65 & 6.92 & 91 & 9 \\
\hline \multirow[t]{3}{*}{83} & 2 & 160 & 9.77 & 0.062 & 0.0534 & $4.5 \times 10^{-5}$ & 8.36 & 1.15 & 9.51 & 88 & 12 \\
\hline & 3 & 200 & 12.51 & 0.062 & & & 10.48 & 1.80 & 12.28 & 85 & 15 \\
\hline & 1 & 120 & 7.30 & 0.061 & & & 6.53 & 0.83 & 7.36 & 89 & 11 \\
\hline \multirow[t]{3}{*}{84} & 2 & 160 & 10.3 & 0.064 & 0.0544 & $5.75 \times 10^{-5}$ & 8.70 & 1.47 & 10.17 & 85 & 15 \\
\hline & 3 & 200 & 13.25 & 0.066 & & & 10.68 & 2.3 & 12.98 & 82 & 18 \\
\hline & 1 & 140 & 7.76 & 0.055 & & & 5.95 & 1.76 & 7.71 & 77 & 23 \\
\hline \multirow[t]{3}{*}{85} & 2 & 180 & 10.72 & 0.059 & 0.0425 & $9.00 \times 10^{-5}$ & 7.65 & 2.92 & 10.57 & 72 & 28 \\
\hline & 3 & 220 & 13.67 & 0.062 & & & 9.35 & 4.35 & 13.70 & 68 & 32 \\
\hline & 1 & 150 & 6.54 & 0.044 & & & 5.43 & 1.12 & 6.55 & 83 & 17 \\
\hline \multirow[t]{3}{*}{86} & 2 & 190 & 8.64 & 0.045 & 0.0362 & $5.00 \times 10^{-5}$ & 6.87 & 1.81 & 8.68 & 79 & 21 \\
\hline & 3 & 230 & 10.96 & 0.048 & & & 8.32 & 2.64 & 10.96 & 76 & 24 \\
\hline & 1 & 150 & 9.27 & 0.062 & & & 7.42 & 1.74 & 9.16 & 81 & 19 \\
\hline \multirow[t]{3}{*}{87} & 2 & 190 & 12.06 & 0.063 & 0.0495 & $7.75 \times 10^{-5}$ & 9.90 & 2.79 & 12.69 & 78 & 22 \\
\hline & 3 & 230 & 15.31 & 0.067 & & & 12.37 & 4.10 & 16.47 & 75 & 25 \\
\hline & 1 & 150 & 10.16 & 0.067 & & & 7.77 & 2.45 & 10.22 & 76 & 24 \\
\hline \multirow[t]{3}{*}{88} & 2 & 200 & 14.7 & 0.073 & 0.0518 & $1.09 \times 10^{-4}$ & 10.36 & 4.36 & 14.72 & 70 & 30 \\
\hline & 3 & 250 & 19.75 & 0.079 & & & 12.55 & 6.81 & 19.36 & 65 & 35 \\
\hline & 1 & 150 & 8.77 & 0.058 & & & 7.29 & 1.44 & 8.73 & 83 & 17 \\
\hline \multirow[t]{3}{*}{89} & 2 & 200 & 12.18 & 0.061 & 0.0486 & $6.4 \times 10^{-5}$ & 9.72 & 2.56 & 12.28 & 79 & 21 \\
\hline & 3 & 250 & 16.4 & 0.066 & & & 12.15 & 4.00 & 16.15 & 75 & 25 \\
\hline & 1 & 140 & 9.13 & 0.065 & & & 7.79 & 1.32 & 9.11 & 86 & 14 \\
\hline \multirow[t]{2}{*}{90} & 2 & 180 & 12.27 & 0.068 & 0.0557 & $6.75 \times 10^{-5}$ & 10.03 & 2.18 & 12.21 & 82 & 18 \\
\hline & 3 & 220 & 15.52 & 0.071 & & & 12.25 & 3.27 & 15.52 & 79 & 21 \\
\hline
\end{tabular}



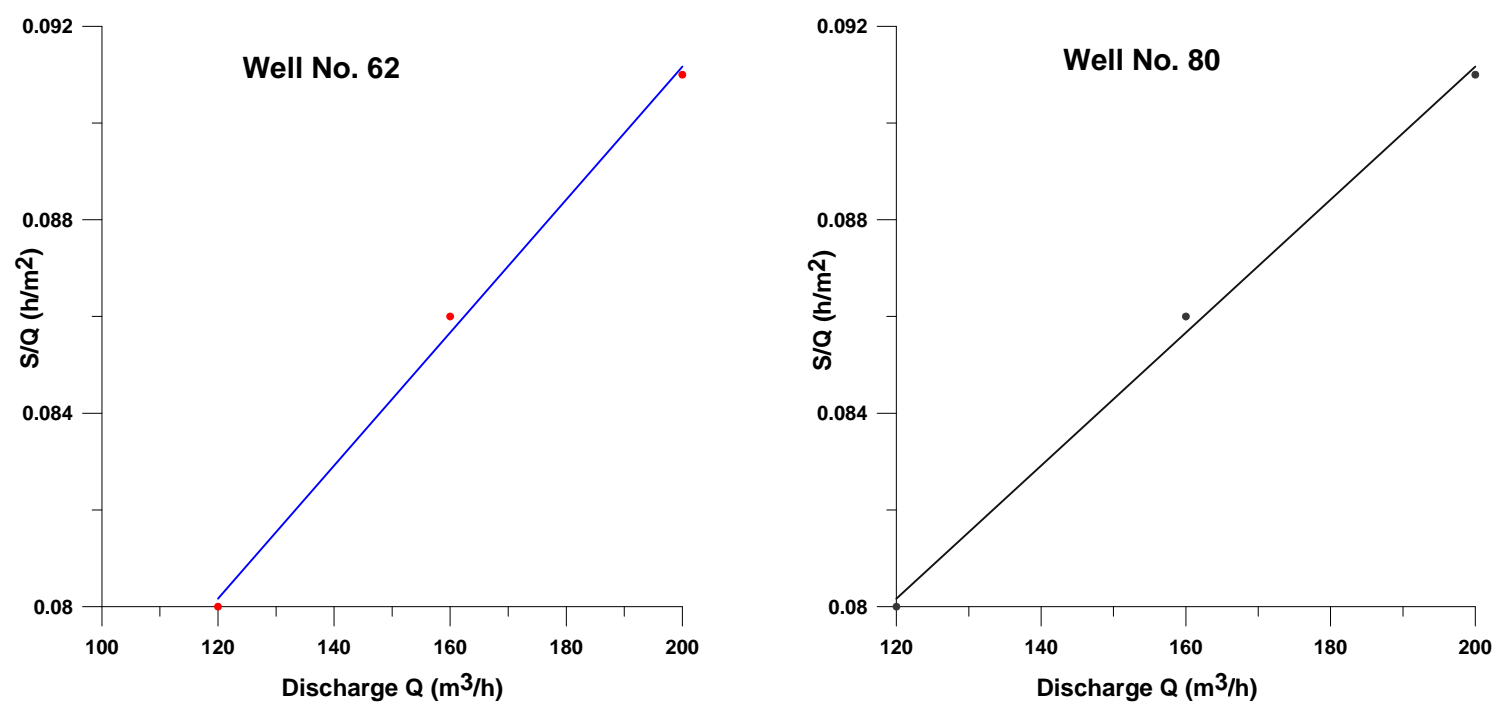

Figure 4. Graph showing the relation between the specific drawdown (S/Q) and discharge (Q).

proper well management, is entrance velocity (Vn) through water well screen. It is suggested that an entrance velocity of $0.03 \mathrm{~m} / \mathrm{second}$ to $0.0762 \mathrm{~m} / \mathrm{second}$ barely lifts sand $0.25 \mathrm{~mm}$ to $0.50 \mathrm{~mm}$ diameter, whilst a velocity of $0.018288 \mathrm{~m} / \mathrm{second}$ barely lifts clay or silt (Smith [12]). It is readily acknowledged that entrance velocity is an integral component of well design, model studies clearly indicate that the range of a relatively acceptable entrance velocity is actually considerably $0.03 \mathrm{~m} / \mathrm{second}$ (R.M.C [13]). The usual index, used to determine the tendency of flow to become laminar or turbulent, is the Reynolds number (NR) which is defined as follows:

$$
\mathrm{NR}=\mathrm{Vd} / \mathrm{v}
$$

where $\mathrm{V}$ is the velocity $(\mathrm{m} / \mathrm{min}), \mathrm{d}$ is the grain diameter, and $v$ is the viscosity of water.

Experimental work on uniform spherical sand grains influences that departure from laminar flow begins at value of NR between 1 and 10. Secondly, if the values of $\mathrm{d}$ and $v$ are nearly the same in a particular area, the increase in the value of $\mathrm{V}$ causes more turbulence resulting in higher well loss. The entrance velocity $(\mathrm{Vn})$, is defined as the pumping rate of flow $(\mathrm{Q})$ in $\mathrm{m}^{3} / \mathrm{h}$ divided by the working area of screen (Ar) in $\mathrm{m}^{2}$ as follows:

$$
\mathrm{Vn}=\mathrm{Q} / \mathrm{Ar}
$$

Using this equation, entrance velocities for the proposed discharging rate $\left(200 \mathrm{~m}^{3} / \mathrm{h} / \mathrm{well}\right)$ for all drilled wells except well N0. $61\left(250 \mathrm{~m}^{3} / \mathrm{h}\right)$ in the concerned area were calculated and tabulated in Table 3. For well design in the study area, the working area of screen equals 0.05 $\mathrm{m}^{2}$ for each meter. The entrance velocities, thus estimated vary from $31.46 \mathrm{~m} / \mathrm{h}$ (well No. 75 ) to $89.72 \mathrm{~m} / \mathrm{h}$ (well No. 84) with an average of about $45.66 \mathrm{~m} / \mathrm{h}$, which is quite high.

\section{Results and Discussion}

As was stated before, the transmisivity (T) and specific capacity $(\mathrm{Sc})$ depend on the well loss in a pumping well, which in turn resulting from: 1) the turbulent flow in the zone outside the well i.e. in the gravel pack, 2) the turbulent flow through the well screen (entrance velocity of water), and 3) the turbulent flow inside the well to the pump intake. So, in the present work, an attempt was made to find out the relationship between these hydraulic parameters for the purpose of well and aquifer proper management as follows.

\subsection{Empirical Relationship between Transmissivity and Specific Capacity}

Specific capacity is useful for estimating transmissivity in aquifers that have few good pump tests. One approach of estimating transmissivity from specific capacity is to use analytical equations such as those derived by Thomasson et al. [14], and Theis [15]. However, Razack and Huntley [16], and Huntley et al. [17] showed that the analytical solutions assume negligible well loss and a homogenous, isotropic, granular aquifer. Instead of using analytical equations, Razack and Huntley [16], and Huntley et al. [17] developed empirical relationships between transmissivity and specific capacity for each aquifer.

In the concerned aquifer, the relationships are usually derived from a first order linear regression using the values of transmissivity (from pumping) and measured specific capacity both in $\mathrm{m}^{2} /$ day units listed in Table $\mathbf{1}$. The best-fitting line between these parameters indicates a positive relationship with moderate coefficient of determination, $\mathrm{R}^{2}$, equals 0.370929 as follows (Figure 5):

$$
\mathrm{T}=2.528615525(\mathrm{Sc})+150.8890325
$$


Table 3. Entrance velocity of water in wells, for the proposed discharging rate in El Shab area.

\begin{tabular}{|c|c|c|c|c|c|}
\hline Well No. & $\begin{array}{c}\text { Proposed Discharge } \\
\mathrm{Q}\left(\mathrm{m}^{3} / \mathrm{h}\right)\end{array}$ & $\begin{array}{l}\text { Length of Slotted Pipe } \\
(\mathrm{m})\end{array}$ & $\begin{array}{c}\text { Total Open Area Ar } \\
\left(\mathrm{m}^{2}\right)\end{array}$ & $\begin{array}{c}\text { Entrance Velocity } \\
\mathrm{Vn}(\mathrm{m} / \mathrm{h})\end{array}$ & $\begin{array}{l}\text { Length from the Pump to } \\
\text { the First Slotted Pipe (m) }\end{array}$ \\
\hline 61 & 250 & 114.2 & 6.037 & 41.41 & 35.80 \\
\hline 62 & 200 & 46 & 2.379 & 84.06 & 44.00 \\
\hline 63 & 200 & 102.29 & 5.407 & 36.99 & 52.58 \\
\hline 64 & 200 & 108.61 & 5.742 & 34.83 & 52.39 \\
\hline 65 & 200 & 115.8 & 6.122 & 32.66 & 52.20 \\
\hline 66 & 200 & 85.86 & 4.539 & 44.06 & 50.84 \\
\hline 67 & 200 & 85.88 & 4.540 & 44.05 & 63.62 \\
\hline 68 & 200 & 72.2 & 3.017 & 66.29 & 54.80 \\
\hline 69 & 200 & 67.3 & 3.558 & 56.21 & 62.70 \\
\hline 70 & 200 & 76.52 & 4.045 & 49.44 & 52.98 \\
\hline 71 & 200 & 76.94 & 4.067 & 49.17 & 61.06 \\
\hline 72 & 200 & 80.01 & 4.229 & 47.29 & 50.49 \\
\hline 73 & 200 & 63 & 3.33 & 60.06 & 45.00 \\
\hline 74 & 200 & 89.17 & 4.714 & 42.42 & 56.36 \\
\hline 75 & 200 & 119.69 & 6.356 & 31.46 & 48.71 \\
\hline 76 & 200 & 98.64 & 5.215 & 38.35 & 58.49 \\
\hline 77 & 200 & 114.29 & 6.042 & 33.10 & 58.36 \\
\hline 78 & 200 & 102.51 & 5.419 & 36.91 & 58.41 \\
\hline 79 & 200 & 114.24 & 6.039 & 33.12 & 54.07 \\
\hline 80 & 200 & 85.79 & 4.535 & 44.10 & 64.32 \\
\hline 81 & 200 & 85.93 & 4.542 & 44.03 & 47.12 \\
\hline 82 & 200 & 111.68 & 5.904 & 33.87 & 64.32 \\
\hline 83 & 200 & 45.88 & 2.425 & 82.47 & 47.12 \\
\hline 84 & 200 & 42.17 & 2.229 & 89.72 & 46.83 \\
\hline 85 & 200 & 108.69 & 5.746 & 34.81 & 58.31 \\
\hline 86 & 200 & 108.81 & 5.752 & 34.77 & 63.19 \\
\hline 87 & 200 & 108.88 & 5.756 & 34.74 & 60.12 \\
\hline 88 & 200 & 102.78 & 5.433 & 36.81 & 52.22 \\
\hline 89 & 200 & 103 & 5.445 & 36.73 & 60.50 \\
\hline 90 & 200 & 105.08 & 5.555 & 36.00 & 58.42 \\
\hline
\end{tabular}

This established empirical equation can be used to predict the transmissivity of the Nubian aquifer in all new sites for well drilling at which the specific capacity measured without performing, longer-term pump testing, which is expensive, but with low potential error of prediction.

\subsection{Empirical Relationship of Well Losses Constant with Transmissivity and Specific Capacity}

The empirical relationships between well losses constant $\left(\mathrm{C}\right.$ in $\left.\mathrm{d}^{2} / \mathrm{m}^{5}\right)$ for 30 drilled wells in El Shab area, with transmissivity $(\mathrm{T})$ and specific capacity $(\mathrm{Sc})$ both in $\mathrm{m}^{2} /$ day units with their best fit lines are shown in Figure 6.

The specific empirical equation for the transmissivity with very low coefficient of determination, $\mathrm{R}^{2}$, equals 0.000595893 is as follow:

$$
\mathrm{C}=1.46850396 \times 10^{-6}(\mathrm{~T})+0.04754387247
$$

The slope of best fit line for these two parameters (C and $\mathrm{T}$ ) does not indicate a definite trend. However, a correction can be made on transmissivity values that can be estimated from the well loss constant obtained from graphical method of step-test data with the quite acceptable of the error percentages.

In contrast, the relationship between well losses constant and specific capacity shows a negative linear relation with low coefficient of determination, $\mathrm{R}^{2}$, equals 0.0657616 as follows: 


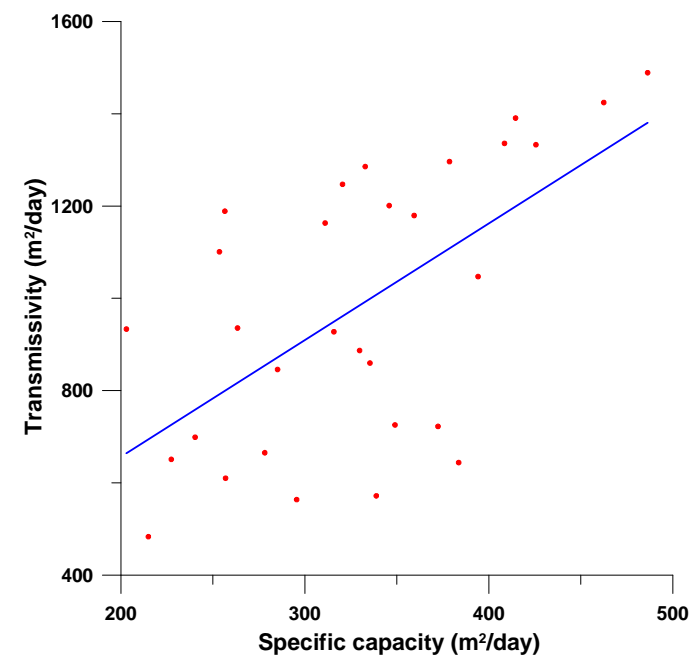

Figure 5. Relationship between transmissivity and specific capacity, showing the best-fit line.
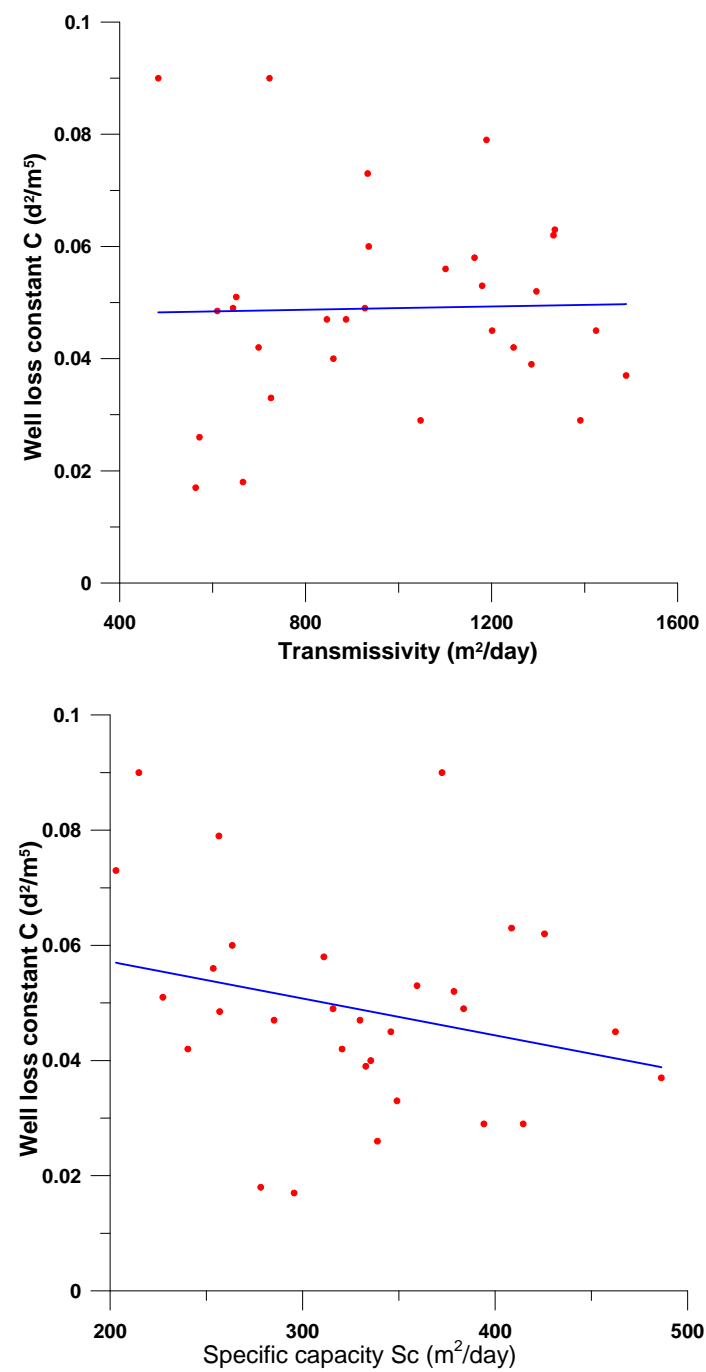

Figure 6. Relationship between well losses constant with transmissivity and specific capacity, showing the best-fit lines.

$$
\begin{aligned}
\mathrm{C} & =-6.404928534 \times 10^{-5}(\mathrm{Sc}) \\
& +0.06999017524
\end{aligned}
$$

This equation shows that, the productivity of a well increases as the well loss constant decreases. If (C) equals zero the specific capacity only reflected the productivity of the aquifer with no miscalculation.

\subsection{Relationship of Well Loss Percentage for a Proposed Discharge Rate to Both Entrance Velocity and Distance from the Entrance Point to the Intake Point}

In the concerned area, the factors which cause the main parts of well losses (\%) are the entrance velocity of waters in wells $(\mathrm{Vn}$ in $\mathrm{m} / \mathrm{h})$ through the working area of screen and the distance from the entrance point to the intake point ( $\mathrm{D}$ in $\mathrm{m}$ ). The percentages of well losses estimated for a proposed discharge rate from the wells listed in Table 4 are plotted against the calculated entrance velocity for the same discharging rate as well as the distance from the pump to the first slotted pipe in each well (Table 3).

The scatter of points for nearly $85 \%$ of the wells on the graph for the relation between well losses (\%) and entrance velocities (Figure 7), indicates a relatively positive and fitting relation between these factors with low coefficient of determination, $\mathrm{R}^{2}$, equals 0.0107456 as follows:

$$
\begin{aligned}
\text { Well loss }(\%) & =0.06947448686 \mathrm{Vn} \\
& +22.36387789
\end{aligned}
$$

This equation shows that the well loss increases with higher values of entrance velocities and accordingly with the lower values of screen working area.

Moreover, the plot between Well losses (\%) and the distance from the entrance point to the intake point (Figure 7), confirms the dependence of Well losses (\%) with (D), with low coefficient of determination, $\mathrm{R}^{2}$, equals 0.0788977 as follows:

$$
\begin{aligned}
\text { Well loss }(\%)= & 0.3279274846 \mathrm{D} \\
& +5.724344884
\end{aligned}
$$

Equation (13) shows that the well loss factor increases as the distance from the point of entrance of water into the well to the pump intake increases.

Accordingly, it can be inferred that these might be the main causes for high well losses in the drilled wells constructed in El Shab area. Another factor contributing to the well loss is the turbulent due to the clogging of gravel pack itself by the formation materials, the pack becomes ineffective in its purpose and causes higher well losses.

Based on the above discussion and my experience in other areas, it is felt that this might form a considerable 
Table 4. Well losses estimated for a proposed discharge rate from the wells, in El Shab area.

\begin{tabular}{|c|c|c|c|c|c|c|c|c|}
\hline Well No. & $\begin{array}{c}\text { Proposed Discharge } \\
\text { Q }\left(\mathrm{m}^{3} / \mathrm{h}\right)\end{array}$ & $\begin{array}{c}\text { Form. Loss } \\
\text { Coef B }\left(\mathrm{h} / \mathrm{m}^{2}\right)\end{array}$ & $\begin{array}{l}\text { Well Loss Coef. } \\
\qquad\left(\mathrm{h}^{2} / \mathrm{m}^{5}\right)\end{array}$ & $\begin{array}{l}\text { Form. Loss } \\
\text { BQ (m) }\end{array}$ & $\begin{array}{l}\text { Well Loss } \\
\text { CQ }^{2}(\mathrm{~m})\end{array}$ & $\begin{array}{c}\text { Total D.D } \\
\text { BQ }+\mathrm{CQ}^{2}(\mathrm{~m})\end{array}$ & $\begin{array}{l}\text { Well Efficiency } \\
\% \text { (BQ\%) }\end{array}$ & $\begin{array}{l}\text { Well Loss } \\
\%\left(C^{2} \%\right)\end{array}$ \\
\hline 61 & 250 & 0.0672 & $8.42 \times 10^{-5}$ & 16.8 & 5.26 & 20.06 & 84 & 16 \\
\hline 62 & 200 & 0.0778 & $1.57 \times 10^{-4}$ & 15.56 & 6.28 & 21.64 & 72 & 28 \\
\hline 63 & 200 & 0.0323 & $2.9 \times 10^{-5}$ & 6.46 & 1.16 & 7.62 & 85 & 15 \\
\hline 64 & 200 & 0.0409 & $8.45 \times 10^{-5}$ & 8.18 & 3.35 & 11.53 & 71 & 29 \\
\hline 65 & 200 & 0.0559 & $8.1 \times 10^{-5}$ & 11.18 & 3.24 & 14.52 & 78 & 22 \\
\hline 66 & 200 & 0.0637 & $8 \times 10^{-5}$ & 12.74 & 3.2 & 15.94 & 80 & 20 \\
\hline 67 & 200 & 0.0524 & $7 \times 10^{-5}$ & 10.48 & 2.8 & 13.28 & 79 & 21 \\
\hline 68 & 200 & 0.0939 & $7.26 \times 10^{-5}$ & 18.78 & 2.9 & 21.68 & 87 & 13 \\
\hline 69 & 200 & 0.0349 & $1.57 \times 10^{-4}$ & 6.58 & 6.28 & 12.66 & 52 & 48 \\
\hline 70 & 200 & 0.0747 & $3.12 \times 10^{-5}$ & 14.54 & 1.25 & 15.79 & 92 & 8 \\
\hline 71 & 200 & 0.0476 & $5.12 \times 10^{-5}$ & 9.52 & 2.05 & 11.57 & 82 & 18 \\
\hline 72 & 200 & 0.0942 & $8.92 \times 10^{-5}$ & 18.84 & 3.57 & 22.41 & 76 & 24 \\
\hline 73 & 200 & 0.0896 & $1.27 \times 10^{-4}$ & 17.52 & 5.08 & 22.60 & 77 & 23 \\
\hline 74 & 200 & 0.0586 & $7.87 \times 10^{-5}$ & 11.72 & 3.15 & 14.87 & 79 & 21 \\
\hline 75 & 200 & 0.0324 & $1.07 \times 10^{-4}$ & 6.48 & 4.28 & 10.76 & 60 & 40 \\
\hline 76 & 200 & 0.0545 & $1.00 \times 10^{-4}$ & 10.90 & 4.00 & 14.90 & 73 & 27 \\
\hline 77 & 200 & 0.0727 & $9.75 \times 10^{-5}$ & 14.54 & 3.90 & 18.44 & 79 & 21 \\
\hline 78 & 200 & 0.0666 & $1.05 \times 10^{-4}$ & 13.32 & 4.20 & 17.52 & 76 & 24 \\
\hline 79 & 200 & 0.0582 & $7.25 \times 10^{-5}$ & 11.64 & 2.9 & 14.54 & 80 & 20 \\
\hline 80 & 200 & 0.0636 & $1.37 \times 10^{-4}$ & 12.72 & 5.48 & 18.2 & 70 & 30 \\
\hline 81 & 200 & 0.0555 & $8.5 \times 10^{-5}$ & 11.10 & 3.40 & 14.50 & 77 & 23 \\
\hline 82 & 200 & 0.0467 & $9.25 \times 10^{-5}$ & 9.34 & 3.70 & 10.04 & 63 & 37 \\
\hline 83 & 200 & 0.0534 & $4.5 \times 10^{-5}$ & 10.48 & 1.80 & 12.28 & 85 & 15 \\
\hline 84 & 200 & 0.0544 & $5.75 \times 10^{-5}$ & 10.68 & 2.3 & 12.98 & 82 & 18 \\
\hline 85 & 200 & 0.0425 & $9 \times 10^{-5}$ & 8.50 & 3.60 & 12.10 & 70 & 30 \\
\hline 86 & 200 & 0.0362 & $5.00 \times 10^{-5}$ & 7.24 & 2.00 & 9.24 & 78 & 22 \\
\hline 87 & 200 & 0.0495 & $7.75 \times 10^{-5}$ & 9.90 & 3.10 & 13.00 & 76 & 24 \\
\hline 88 & 200 & 0.0518 & $1.09 \times 10^{-4}$ & 10.36 & 4.36 & 14.72 & 70 & 30 \\
\hline 89 & 200 & 0.0486 & $6.4 \times 10^{-5}$ & 9.72 & 2.56 & 12.28 & 79 & 21 \\
\hline 90 & 200 & 0.0557 & $6.75 \times 10^{-5}$ & 11.14 & 2.7 & 13.84 & 80 & 20 \\
\hline
\end{tabular}
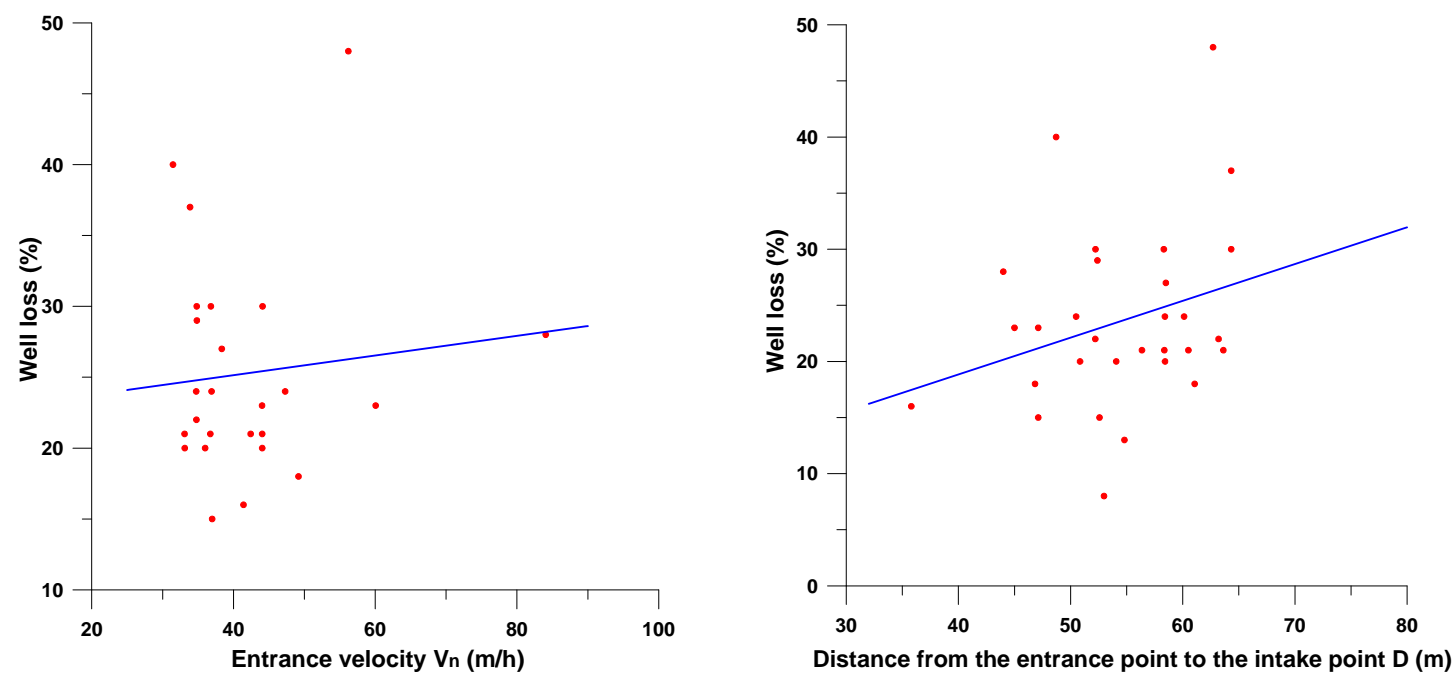

Figure 7. Relationship between well loss (\%) with entrance velocity and distance from the entrance point to the intake point, showing the best-fit line. 
part of the total well loss. For the well designer, this has important relevance when selecting the type and amount of well screen for a new well as well as the pump position.

\section{Conclusions and Recommendations}

In El Shab area, groundwater of the Nubian Sandstone aquifer is the unique source of fresh water. This aquifer has a large range of transmissivity (from 483.12 to $1489.24 \mathrm{~m}^{2} /$ day) and, also, specific capacity (from 203 to $486.32 \mathrm{~m}^{2} /$ day). It has been shown that, the percentage of well loss in the drilling wells varies from $2 \%$ to $48 \%$ with an average of about $25 \%$. In contrast, the well efficiency varies from $52 \%$ to $98 \%$ (well No. 70 ), with an average of about $75 \%$. For the present discharge rate, 10 wells having the well loss less than $20 \%$ (well efficiency $<90 \%$ ), and the other wells ( 20 wells) in the range of $21 \%$ - 48\% (well efficiency between $80 \%$ and $50 \%$ ). This leads to the understanding that in nearly $70 \%$ of the drilled wells in the area, excessive well losses are observed. An attempt was made to evaluate the factors causing excessive well losses so that remedial measures can be adopted in the design aspects of the drilled wells. The calculations of entrance velocities of water into the screen have shown that all values are failing in the range 31.46 to $89.72 \mathrm{~m} / \mathrm{h}$ with an average of about $45.66 \mathrm{~m} / \mathrm{h}$, which is quite high. As such, the full open area of the slots, assumed for the calculations for entrance velocity, may not be available for the water to flow freely, which in turn causes excess well losses. Another factor contributing to the well loss is turbulent flow inside the well due to the high distance from the screen to the pump intake in the drilling wells (from 25 to $42 \mathrm{~m}$ ). The established relationships between well losses constant with transmissivity and specific capacity indicate, indefinite clear trend relation for transmissivity with very low coefficient of determination, $R^{2}(0.000595893)$, and a negative linear relation for specific capacity with a low coefficient of determination (0.0657616) respectively.

Based on the above results, the following recommenddations should be taken into consideration in the design of water wells for proper management:

1) Well should have better graded gravel packs. The angular pack materials should be avoided and consequently clogging of formation material in the same.

2) Maximizing the open area of screen than has adopted at present to minimize the entrance velocity of water into the well as well as the well loss percentage. Increasing the present screen working area by $20 \%\left(0.07 \mathrm{~m}^{2}\right.$ for each screen meter) will decrease the entrance velocity by about $25 \%$ and hence the well loss percent by about $6 \%$ (Equation (12)).

3) Screen materials should be corrosion resistant.

4) The distance from the pump intake to the point of water entrance into the well (screen position) has a bearing on the well losses. In order to minimize the well losses, the pump may have to be lowered to depth closer to the screen, taking into consideration the economics involved in the lift vis a vis a maximum limit of permissible well loss. Increasing the current distance between the pump and the screen by $20 \%$ will increase the well loss percent by $7 \%$ (Equation (13)).

\section{REFERENCES}

[1] CONOCO, "Geologic Map of Egypt, Scale 1:500,000," Continental Oil Company, 1989.

[2] R. Fathy, M. Hefnawy and A. Abdel Hamid, "Contributions to the Hydrogeology Aspects of the Groundwater Aquifer in Southern Part of Darb El Arbaein Area, Southern Portion of Western Desert, Egypt," Al-Azhar Bulletin of Science, Vol. 12, No. 2, 2001, pp. 175-194.

[3] E. Korany, G. Fathy and M. El Nagaty, "Contributions to the Hydrogeology of Nubian Sandstone Aquifer in the Middle Part of Darb El Arbaein, South Western Desert, Egypt," Sedimentology of Egypt, Vol. 10, 2002, pp. 119143.

[4] A. Ghazal, "Hydrogeological Studies in Darb El Arbaein area, Southwestern Desert, Egypt," Master Science, Geology Department, Cairo University, Cairo, 2002.

[5] N. El Gammal, "Hydrogeological Studies in Darb El Arbaein Area, South Egypt," Master Science, Geology Department, Cairo University, Cairo, 2004.

[6] B. Issawi, "Geology of Southeastern Corner of Western Desert,” Ann GSE Cairo, Vol. 8, No. 3, 1973, pp. 25-30.

[7] Ministry of Water Resources and Irrigation (MWRI), "Hydrogeological Data of Water Wells in Darb El Arbaein Area, Western Desert, Egypt," Internal Unpublished Report, 2010.

[8] C. E. Jacob, "Flow of Groundwater. Engineering Hydraulics," John Wiley, New York, 1950.

[9] H. B. Eagon Jr. and D. E. Johe, "Practical Solutions for Pumping Tests in Carbonate-Rock Aquifers," Ground Water, Vol. 10, No. 4, 1972, pp. 6-13. doi:10.1111/j.1745-6584.1972.tb02929.x

[10] M. J. Rorabaugh, "Graphical and Theoretical Analysis of Step Drawdown Test of Artesian Well," Proceedings of the American Society of Civil Engineers, Vol. 79, No. 362, 1953, pp. 1-23.

[11] G. P. Kruseman and N. A. de Ridder, "Analysis and Evaluation of Pumping Test Data," 2nd Edition, Wageningen Academic Publishers, Wageningen, 1990.

[12] E. R. Smith, "Screen Bore Construction," Sydney, Water Research Foundation of Australia, Report No. 24, 1966.

[13] Roscoe Moss Company, "Handbook of Ground Water Development," John Wiley and Sons, New York, 1990.

[14] H. J. Thomasson, F. H. Olmsted and E. R. LeRoux, "Geology, Water Resources, and Usable Groundwater Storage Capacity of Part of Solano County. CA. US," Geological Survey Water Supply Paper 1464, 1960. 
[15] C. V. Theis, "Estimating Transmissivity of Water-Table Aquifer from Specific Capacity of a Well," Geological Survey Water Supply Paper 1536-I, 1963, pp. 332-336.

[16] M. Razack and D. Hantley, "Assessing Transmissivity from Specific Capacity in a Large and Heterogeneous Alluvial Aquifer," Ground Water, Vol. 29, No. 6, 1991, pp. 856-861. doi:10.1111/j.1745-6584.1991.tb00572.x

[17] D. Hantley, R. Nommensen and D. Steffey, "The Use of Specific Capacity to Assess Transmissivity in FracturedRock Aquifers," Ground Water, Vol. 30, No. 3, 1992, pp. 396-402. doi:10.1111/j.1745-6584.1992.tb02008.x 